\title{
Engineering and environmental remediation scenarios due to leakage from the Gulf War oil spill using 3-D numerical contaminant modellings
}

\author{
Yohannes Yihdego' ${ }^{1}$ Radwan A. Al-Weshah ${ }^{2,3}$
}

Received: 20 August 2016/Accepted: 7 December 2016/Published online: 22 December 2016

(C) The Author(s) 2016. This article is published with open access at Springerlink.com

\begin{abstract}
The transport groundwater modelling has been undertaken to assess potential remediation scenarios and provide an optimal remediation options for consideration. The purpose of the study was to allow 50 years of predictive remediation simulation time. The results depict the likely total petroleum hydrocarbon migration pattern in the area under the worst-case scenario. The remediation scenario simulations indicate that do nothing approach will likely not achieve the target water quality within 50 years. Similarly, complete source removal approach will also likely not achieve the target water quality within 50 years. Partial source removal could be expected to remove a significant portion of the contaminant mass, but would increase the rate of contaminant recharge in the short to medium term. The pump-treat-reinject simulation indicates that the option appears feasible and could achieve a reduction in the area of the $0.01 \mathrm{mg} / \mathrm{L} \mathrm{TPH}$ contour area for both Raudhatain and Umm Al-Aish by 35 and 30\%, respectively, within 50 years. The rate of improvement and the completion date would depend on a range of factors such as bore field arrangements, pumping rates, reinjection water quality and additional volumes being introduced and require further optimisation and field pilot trials.
\end{abstract}

Yohannes Yihdego

yohannesyihdego@gmail.com

1 Snowy Mountains Engineering Corporation (SMEC), Sydney, NSW 2060, Australia

2 Department of Civil Engineering, The University of Jordan, Amman 11942, Jordan

3 Kuwait Environmental Remediation Project, Kuwait City, Kuwait
Keywords Contamination · Oil · Hydrocarbon · Pollution · Groundwater remediation · Numerical modelling · Persian Gulf · Iraq war

\section{Introduction}

Organic contaminants may enter the subsurface as slightly soluble and volatile non-aqueous phase liquids or as dissolved solutes resulting in contaminant plumes. Over the last two decades, understanding of the fate of dissolved organic plumes has been advanced by recognition of the importance of anaerobic biodegradation, multiple redox zones, microbial enzyme kinetics, and mixing of organic contaminants and electron acceptors at plume fringes. Significant research has been devoted across the globe to characterising and understanding processes controlling the transport and fate of these organic contaminants and the effectiveness of natural attenuation, bioremediation and other remedial technologies including coastal areas (Essaid et al. 2015; Hu et al. 2015; Rasa et al. 2013; Suthersan et al. 2016; Yihdego and Eslamian 2016; Yihdego 2015, Yihdego 2016a, b).

Oil spills and leakage from burning oil wells in Kuwait in 1991 sourced hydrocarbon as well as saline intrusion to extinguish the fire, contaminated an alluvial aquifers in Kuwait in 1991. The location(s) and nature of the pollution source zone(s) were unknown, and the dissolved concentrations of volatile organic compounds in the monitoring wells varied greatly with time. The aquifer was in hydraulic equilibrium with an artificial canal whose water level was highly variable (up to $5 \mathrm{~m}$ ). These variations propagated into the aquifer, causing changes in the groundwater flow direction. A transient numerical model of flow and solute transport showed that they correlate with 
the concentration variations because the changes in the flow direction resulted in the contaminant plume shifting. The transient hydrogeological numerical model was built, taking into account solvent biodegradation with first-order chain, since biodegradation has a significant influence on the pollutant concentration evolution. The model parameterization confirms the position of the source zones among the potential troughs in the bedrock where dense nonaqueous phase liquids (DNAPL) could have accumulated. The groundwater model was successfully calibrated to reproduce the observed concentration variations over several years and allowed a rapid validation of the hypotheses on the functioning of the polluted system (Yihdego and AlWeshah 2016b). The groundwater modelling of the AlRaudhatain and Umm Al-Aish freshwater aquifer has been undertaken for the purpose of providing a calibrated numerical flow and transport model to assess potential remediation scenarios and provide a preferred remediation option. The modelling involved the construction of a conceptual model and a three-dimensional numerical computer model was constructed using the MODFLOWSURFACT numerical code. Using these codes overcame the limitations of earlier models of the freshwater lenses.

The groundwater model developed for this area is a small part of the larger programme of "restoration" of the freshwater lenses (SMEC 2014). The data and our interpretations have been sourced from consultant reports by SMEC (2014). The ultimate aim of the numerical groundwater modelling is to assess risk and potential remediation scenarios to allow an informed decision to be made on the preferred scenario (Somaratne et al. 2013; Yihdego et al. 2015). Further to the preliminary assessment of the scenarios, the model may be used for optimisation using the results of future pilot field trials. For the purpose of remediation, detection of petroleum-related hydrocarbons in fresh groundwater samples above the drinking water standard is an indication of required remedial action. The assessment of each scenario of treatment is based on estimate of time required for remediation and the extent of removal of contaminants. The model was run from March 1991 till the end of 2063. This is to allow about 50 years of predictive remediation simulation time from the end of 2013 for the remediation scenarios.

\section{Site description}

The study area is located in the northern portion of the Kuwait in the Al Jarha Governorate, near the Raudhatain and Sabriyah oil fields. The Al-Raudhatain-Umm Al-Aish drainage basin (Fig. 1), are the only freshwater aquifers in the country. These freshwater aquifers are unique in that their recharge process reflects the rapid infiltration of surface water runoff and their proximity to the oilfield makes them very vulnerable to contamination. The pollution caused by the destruction of oil wells during the Gulf War of 1991 and sea water used to control and extinguish oil fires has directly affected the aquifers. It has been estimated that about $3.5 \times 10^{6} \mathrm{~m}^{3}$ of oil was spilled from damaged wells and about $240 \times 10^{6} \mathrm{~m}^{3}$ was burnt. The spilled oil was collected in 300 oil lakes, spread over an area of about $49 \mathrm{~km}^{2}$. Out of these, $3.3 \times 10^{6} \mathrm{~m}^{3}$ of oil was recovered and exported later. The rest was left behind, as it was not economically feasible to be recovered. The oil that remained has been subjected to severe weathering over the past 18 years. The total amount of oil lost has been estimated to be in excess of one billion barrels (Sadiq and McCain 1993).

Kuwait is an arid country characterised by long summers with extremely high temperatures and high humidity, short mild winters with low humidity, and high evaporation rates (Grealish et al. 1998). It has no fresh surface water supplies and very limited renewable groundwater. Rare and high intensity rainstorms are observed and can produce surface water runoff through the network of wadis which provide recharge to groundwater aquifers.

The bulk of Kuwait's groundwater is brackish (Omar et al. 1994). Total dissolved solids (TDS) is an important indicator of groundwater quality with values less than 1000 milligrammes/litre (mg/L) considered to represent 'fresh' water. Water supply relies on desalinated water, brackish groundwater and treated wastewater. As of 2011, about half of water supply was provided by desalination and the balance by a combination of mostly brackish groundwater and treated sewage effluent.

\section{Regional geology and hydrogeology}

The geology of Kuwait consists of recent (Quaternary age) deposits and sediments unconformably overlying sedimentary rocks (Tertiary age) which host the groundwater aquifers. Exploration drilling throughout the region has shown sedimentary rocks ranging in age from Cretaceous to Permian. The regional dip of strata is about two metres per kilometre towards the north-east and this regular dip is interrupted by anticlines and other small structures which are present at the Raudhatain oilfield. The Dibdibba Formation, confined to the northern part of Kuwait, comprises sands and gravels with minor clay and gypsiferous sandy clay beds. Hydrogeologically, the two freshwater aquifers of interest are situated beneath the shallow, elongated depression of the Al-Raudhatain-Umm Al-Aish drainage system (Fig. 1), consisting of an extensive network of wadis and drainage lines. The drainage system that leads to these two playas is the most pronounced of the seven main catchments or drainage systems within Kuwait. The 
Fig. 1 Location of the AlRaudhatain and Umm Al-Aish Aquifers in Kuwait

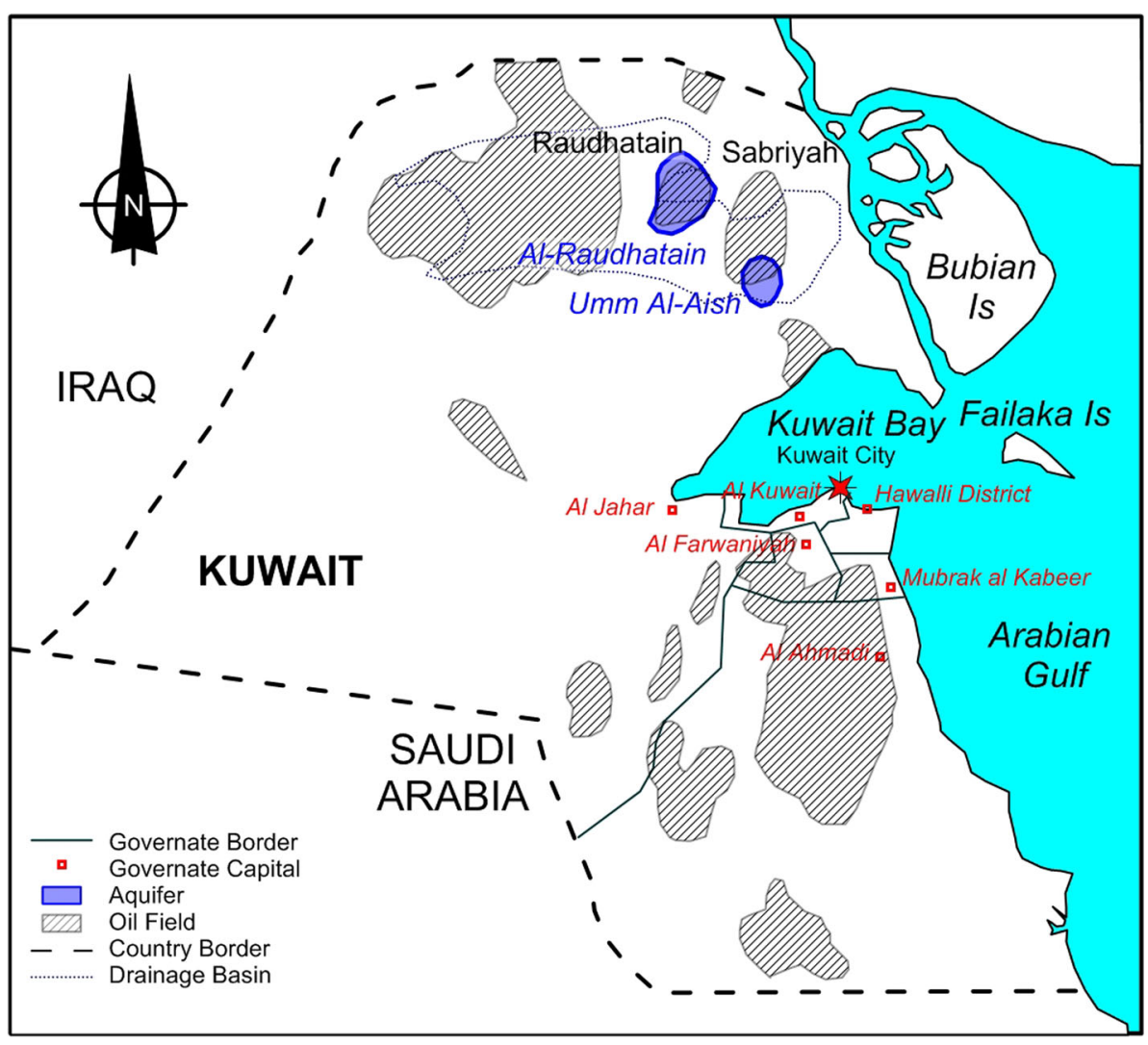

catchment is about $110 \mathrm{~km}$ from south-west to north-east with a maximum width of about $55 \mathrm{~km}$.

\section{Oil and gas extraction}

The petroleum industry in Kuwait is the largest in the country, accounting for nearly half of the country's Gross Domestic Product. There are proven oil reserves of over 100 billion barrels. Production in Kuwait accounts for around seven percent of world-wide oil production with a 2005 estimate of around 2.4 million barrels of oil per day. There are around 13 major oil companies in Kuwait. Oilfields are located throughout the country (Fig. 1). During the Gulf War:

- 798 were destroyed with explosives;

- 604 discharged crude oil and had petroleum gases set ablaze; and

- 45 flowed oil but were not set ablaze.

\section{Groundwater recharge and flow direction}

Rainfall is the primary source of recharge to the freshwater lenses at Al-Raudhatain and Umm Al-Aish. The actual process leading to infiltration is subject to several theories based on limited evidence and is discussed in detail in the Conceptual Model Report. The direction and gradient of flow within the Kuwait Group aquifers essentially follows the stratigraphic dip and is in a northeasterly direction. The gradient steepens in the southeast and reflects discharge to the Arabian Gulf. In the north-east, the gradient flattens and groundwater discharge is largely to coastal sabkhahs (salt flats). The rate of groundwater flow in the central part of the AlRaudhatain well field (based on permeability, porosity and gradient) has been estimated at about $110 \mathrm{~m} /$ year (Parsons 1964). The inferred flow velocity using the flow line distance and the results of ${ }^{14} \mathrm{C}$ and ${ }^{3} \mathrm{H}$ age dating indicated a flow velocity of between 11 and $245 \mathrm{~m} /$ year (Parsons 1964). There is an effective porosity of 0.2 ; and hydraulic conductivity range of $40-80 \mathrm{~m} /$ day (which are considered typical of the upper aquifer in Umm Al-Aish and Al-Raudhatain). These calculations gave an estimated groundwater velocity range of 20-90 m/year (SMEC 2006, 2014).

The gradient of groundwater level and flow for the AlRaudhatain and Umm Al-Aish freshwater aquifers is toward north-easterly direction. This gradient of flow follows the stratigraphic dip eventually discharging to the Arabian Gulf. 


\section{Contamination}

The problem of groundwater monitoring for hydrocarbons and its derivatives is compounded due to the presence of oil fields. Contamination is known to be extensive in the AlRaudhatain and Umm Al-Aish basins from an extensive reconnaissance survey of soil contamination in 2000/2001 (Grealish et al. 2001). Monitoring and measurement of groundwater contamination in the freshwater aquifers commenced in 1995 with specially designated monitoring wells. A large amount of data has been collected on both soil and groundwater contamination.

Previous studies of hydrocarbon pollutants in the groundwater established that the pollution in the $\mathrm{Al}$ Raudhatain and Umm Al-Aish basins is long-term, extending to several years. Under these conditions, microbial degradation may be expected to play an important role in decomposing and degrading the pollutants. Microbial interference can significantly alter the leaching characteristics of pollutants.

There is a significant areal extent of contamination within the Umm Al-Aish Basin and in the south-eastern portion of the Al-Raudhatain Basin. Contamination seems to have penetrated $10-30 \mathrm{~m}$ below the water table. There are high concentration of salt remaining over catchment areas of Umm Al-Aish and Al-Raudhatain that will likely continue to contaminate overland flows in wadis and other parts of the catchments. This may lead to focused points of contaminated recharge to the fresh groundwater lenses. Aerial maps and on-ground reconnaissance has identified dozens of pits and oil lakes used to fight oil well fires.

The quality of groundwater and its pollution in AlRaudhatain and Umm Al-Aish areas has been monitored and documented (Yihdego and Al-Weshah 2016a, b, c). Results indicate that hydrocarbon pollutants pose a threat to the potable aquifers. Higher levels of pollutants were detected in areas which previously did not show any contamination. The Total Petroleum Hydrocarbon (TPH) concentration has been measured between 2004 and 2009 . In 2012, the hydrocarbon cyclohexane was also measured. Figure 2 shows the TPH concentrations in 2009.

Predictive analysis using mathematical models (KISR 2009) underscored the possibility of large-scale contamination of the groundwater resources in the Umm Al-Aish basin, caused by ongoing movement of hydrocarbon pollutants towards the supply bores. Other studies (SMEC 2006) suggested that the groundwater in Umm Al-Aish area has been significantly affected by the hydrocarbon pollutants (Yihdego and Al-Weshah 2016a). It has been predicted that these pollutants would move towards the Al-Raudhatain freshwater lens if no preventive and/or remedial measures were taken in the near future (KISR 2009).

\section{Conceptual hydrogeological model}

The conceptual model was constructed taking into account the key factors influencing the hydrogeology of the area of interest. These may include: recharge, discharge, flow direction, geology, and contamination in the local and regional context. The model is an approximation and presents the understanding of how the hydrogeological system is understood to work (Yihdego and Webb 2015; Yihdego and Paffard 2016; Yihdego and Webb 2016; Yihdego et al. 2016). Figure 3 presents the conceptual hydrogeological model used to develop the numerical model.

\section{Hydrostratigraphy}

The Environmental Visualisation Software EVS-pro threedimensional data presentation programme has been used to build the hydrostratigraphic model using available data from boreholes (260) and geophysical surveys (downhole logging and time domain electromagnetic surveys) to build a database. The database allows for geo-statistical assessment of the data in both two (2-D) and three (3-D) dimensions (Yihdego and Al-Weshah 2016a, b).

\section{Numerical groundwater model}

The groundwater model of the Al-Raudhatain and UmmAl-Aish basins was undertaken (Al-Weshah and Yihdego 2016; Yihdego and Al-Weshah 2016b, c) using the MODFLOW-SURFACT numerical code (HydroGeoLogic, Inc. 2013). MODFLOW-SURFACT is a state of the art simulator that utilises vadose zone flow and transport equations to provide practical solutions to the analysis of flow and contaminant transport at various levels of complexity and sophistication as needed for site evaluation and closure. The variably saturated flow equation can be solved with standard retention functions or multimodal relative permeability curves for unsaturated flow in porous and fractured systems. The equation can further be solved with soil retention functions for confined-unconfined simulations. The variably saturated transport equation can be solved for unsaturated medium or can be used for confined-unconfined situations. It is highly advantageous to have the unsaturated and saturated simulation capabilities in a single code that may be used to analyse all stages within the lifecycle of a site investigation-from pilot point to closure. Benefits of the comprehensive simulation capability include:

1. Scalable solution in terms of detail of conceptualisation, ranging from simple evaluations to more complex and complete investigations. 


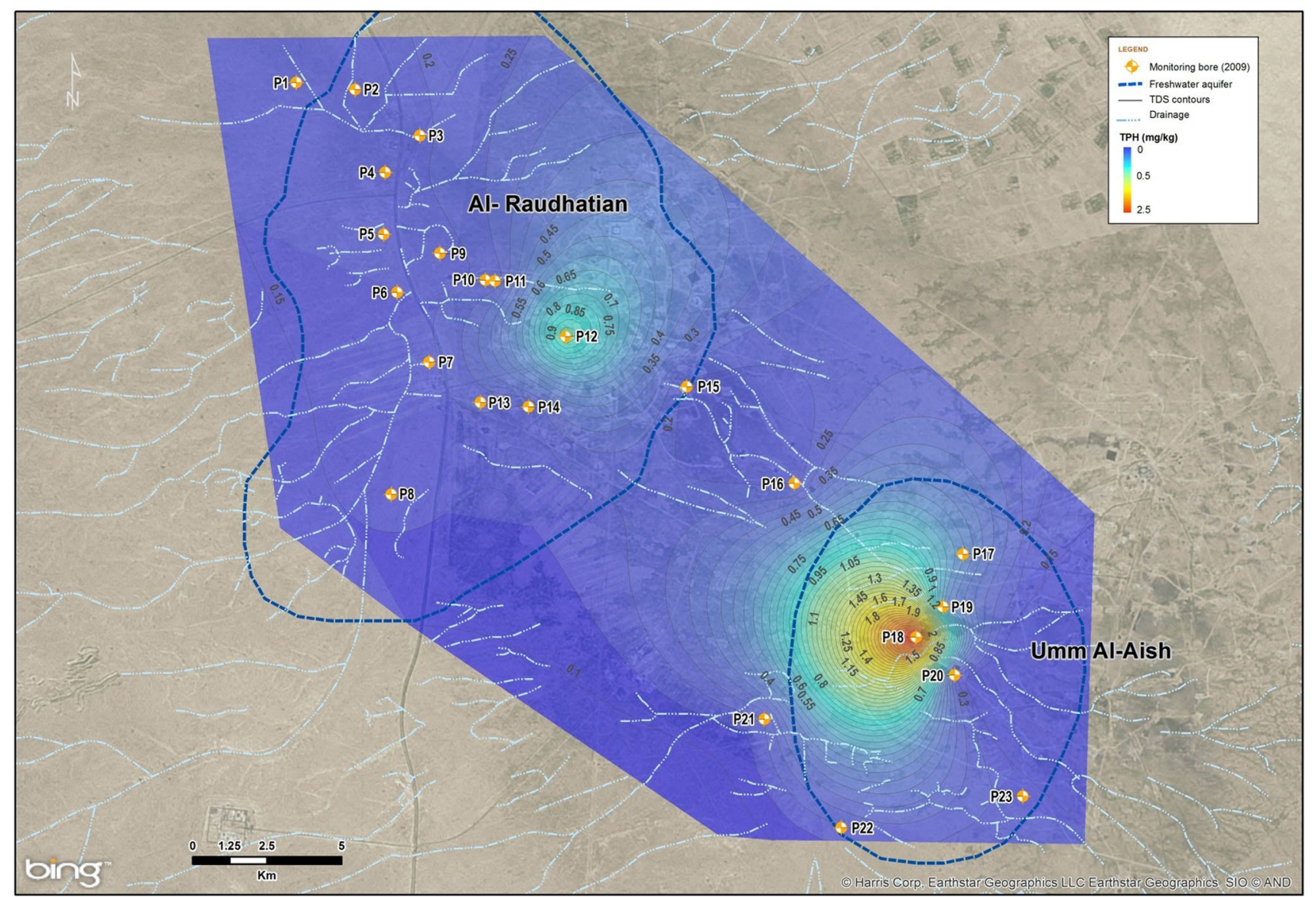

Fig. 2 Location map of the study area showing the aquifers and composite TPH concentrations contours for 2009.*Red region of highest TPH, Blue region of low TPH. With TPH concentration (after Yihdego and Al-Weshah 2016a)

2. Consistent approximations throughout the analyses as opposed to possible differences in results from different codes owing to differences in gridding structures, spatial and temporal discretisation approximations, and material property assignment schemes; and,

3. further, approximations involved in translating from one code to another are avoided.

Overcoming the difficulties and expanding the simulation capability of MODFLOW-MT3D solutions can be done using MODFLOW-SURFACT. This is a comprehensive simulator for set of equations for evaluating multicomponent contaminant transport within multiple phases in the subsurface using the vadose zone flow and transport equations in unique ways to perform the wide range of analysis needed for understanding and managing contamination and remediation projects (Panday and Huyakorn 2008). MODFLOW-SURFACT includes three major classes of transport solution techniques [the standard finitedifference method, the particle-tracking-based EulerianLagrangian methods, and the finite-volume third-order total variation diminishing (TVD) method in a single code].
Since no single numerical technique has been effective for all transport conditions, the combination of these solution techniques, each having its own strengths and limitations, is believed to offer the best approach for solving the most wide-ranging transport problems with efficiency and accuracy. MODFLOW-SURFACT is used for the variably saturated three-dimensional groundwater flow and transport modelling, and is presently considered a code that complies with industry standards. The flow and transport models were calibrated using a manual iterative parameter approach and the parameter optimising programme PEST (Doherty 2004).

\section{Remediation scenarios}

The groundwater modelling undertaken for this area is a small part of the larger programme of "restoration" of the freshwater lenses. The ultimate aim of the numerical groundwater modelling is to assess potential remediation scenarios to allow an informed decision to be made by 


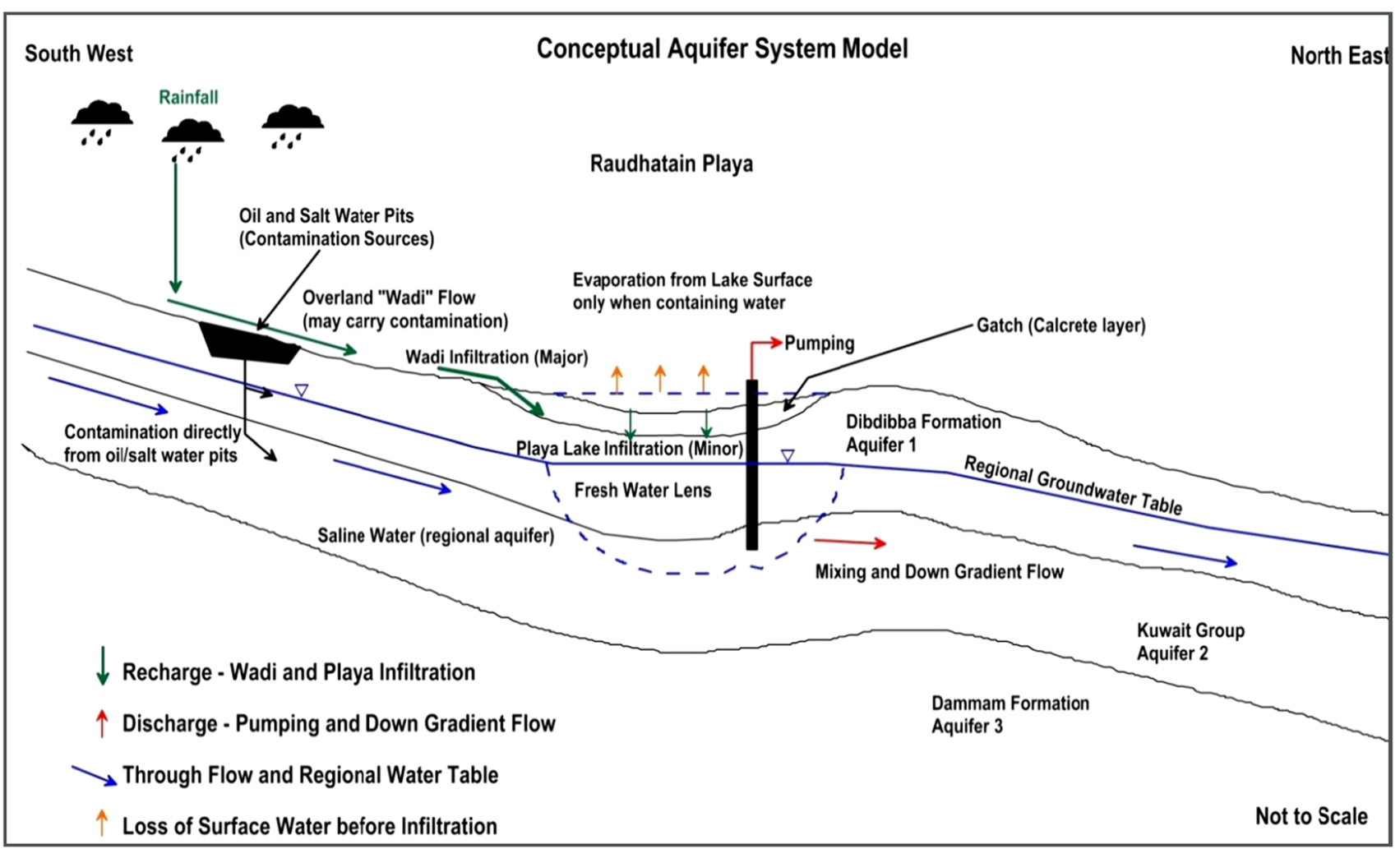

Fig. 3 Idealised conceptual model of the freshwater aquifer systems (after Yihdego and Al-Weshah 2016c)

respective authorities in Kuwait on the preferred scenario. Further to the preliminary assessment of the scenarios, the model may be used for optimisation using the results of future pilot field trials. For the purpose of remediation, detection of petroleum-related hydrocarbons in fresh groundwater samples and total dissolved solids measurements above the drinking water standard $(1500 \mathrm{mg} / \mathrm{L})$ is an indication of required remedial action. The assessment of each scenario of treatment is based on estimate of time required for remediation; and the extent of removal of contaminants (petroleum hydrocarbon and salts). The model was run from March 1991 till the end of 2063. This is to allow about 50 years of predictive remediation simulation time from the end of 2013 for the remediation scenarios. The hydrocarbon contamination is assumed to have first entered the system at the time of the oil well fire fighting in 1991.

\section{Do nothing scenario-natural attenuation}

\section{Modelling runs}

Following the calibration of the contaminant concentration at five target bores, simulation was carried out using MODFLOW-SURFACT for 50 years (beginning year 2013) to determine the likely levels of contamination in the aquifer at different locations, including the observation bores. Chemical reaction (biodegradation) has not been considered in this simulation. Not considering biodegradation will likely overestimate the extent of contamination, therefore the rate of natural attenuation will be underestimated (conservative). Large-scale withdrawal of water from freshwater lenses will also affect the prediction results through its effects on the hydrodynamic gradient, and the transport direction and rate of movement of the pollutants.

Natural, non-enhanced, mostly microbial degradation of organic constituents by which complex organic compounds are broken down to simpler, usually less toxic compounds through aerobic or anaerobic processes can take place at any contaminated site. To rely on this natural process for environmental remediation, there must be assessment of current degradation rates to determine if they are sufficient to control or degrade a contaminant plume or zone without the creation of unacceptable risk to human health or the environment (Guvanasen et al. 2009). In the absence of site-specific data, human-assisted treatment of the contaminated groundwater may be required. In the absence of high resolution investigations, the extent of contaminant migration can only be estimated.

The simulated concentration profiles for total petroleum hydrocarbon and total dissolved solids from 2013 to 2063 


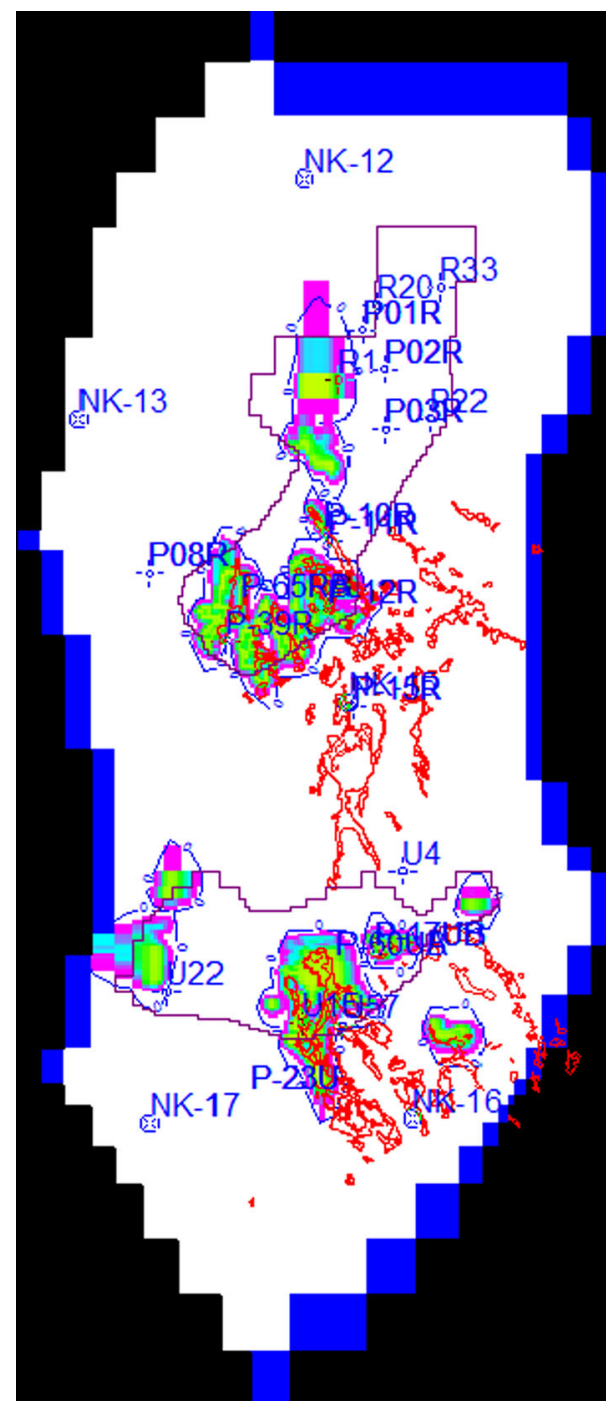

Fig. 4 Predicted distributions of TPH plume in 73 Years (1991-2063) for do nothing scenario. Low TPH concentrations are shaded in light blue and high concentrations are shaded in yellow. Red lines show contamination source areas

at the monitoring bores designated by $\mathrm{P}-18$ and $\mathrm{P}-19$ are presented on Fig. 4. The total petroleum hydrocarbon concentrations slowly increased from about $0.05 \mathrm{mg} / \mathrm{L}$ after approximately a five-year to peak at $1 \mathrm{mg} / \mathrm{L}$ at about 50 years, in monitoring bore P-19 (Fig. 4). Based on the time series simulation, the total petroleum hydrocarbon concentrations increased and the plumes continued to expand. There was no apparent steady state achieved. The maximum total petroleum hydrocarbon concentration after 50 years of simulation is approximately $11.5 \mathrm{mg} / \mathrm{L}$ (at monitoring bore P-18).

Scenario 1 (do nothing) suggests that the contamination plume would continually expand over time. This type of simulation helps to determine whether concentrations will migrate into the freshwater lenses (the receptor represented by the monitoring bores) above some regulatory limit. In this case, the receptors of concern are the two freshwater lenses at Al-Raudhatain and Umm Al-Aish shown as polygons (poly-lines) in Fig. 4.

Figure 4 shows the spatial distribution of total petroleum hydrocarbon in 50 years (2063). This suggests that almost half of the main Umm Al-Aish depression will be contaminated within the next 50 years and the extent of the polluted area will increase with time. In the Al-Raudhatain basin, the contamination appears to be mainly located south of the freshwater lens.

\section{Source removal}

\section{Complete source removal option}

Complete removal of the pollution sources is considered not feasible due to migration of the hydrocarbons into the vadose zone to depth of at least $25 \mathrm{~m}$. However, considering this option provides an assessment of its potential effectiveness and a comparison with the do nothing scenario. It may be considered the opposite end of the remediation spectrum.

For assessment purposes, the vadose zone contamination was assumed to act as the only source of contaminants. However, since lateral and vertical contaminant migration in the vadose zone and subsequent remobilisation by recharge events are considered significant, this assumption is an over simplification of the actual case.

The assumption is that removal of the hydrocarbon source at the surface will negate future downward subsurface pollution. The results indicate that within the 50 year time frame for remediation (2013-2063), the simulated reduction in concentration is not sufficient to reach the clean-up target of $0.01 \mathrm{mg} / \mathrm{L}$ of total petroleum hydrocarbon. Results further suggest that the clean-up target may not be reached within 73 years. Beyond 23 years (the year that surface input concentrations were set to zero) the concentrations decreased to approximately $1.6 \mathrm{mg} / \mathrm{L}$ after 73 years which is still above the acceptable limit (Fig. 5).

\section{Pump-treat-reinject}

Pump and treat and reinject (PTR) typically involves the extraction of contaminant affected groundwater through a range of extraction bores, as well as treatment of the extracted water to reduce contaminant levels. The extraction of groundwater typically induces increased flow rates of groundwater and associated contaminants through the formation, accelerating the transportation of contaminants. Contaminants in the affected saturated and wetted areas of the formation are progressively washed towards the

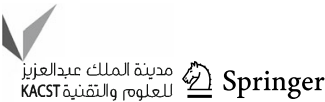




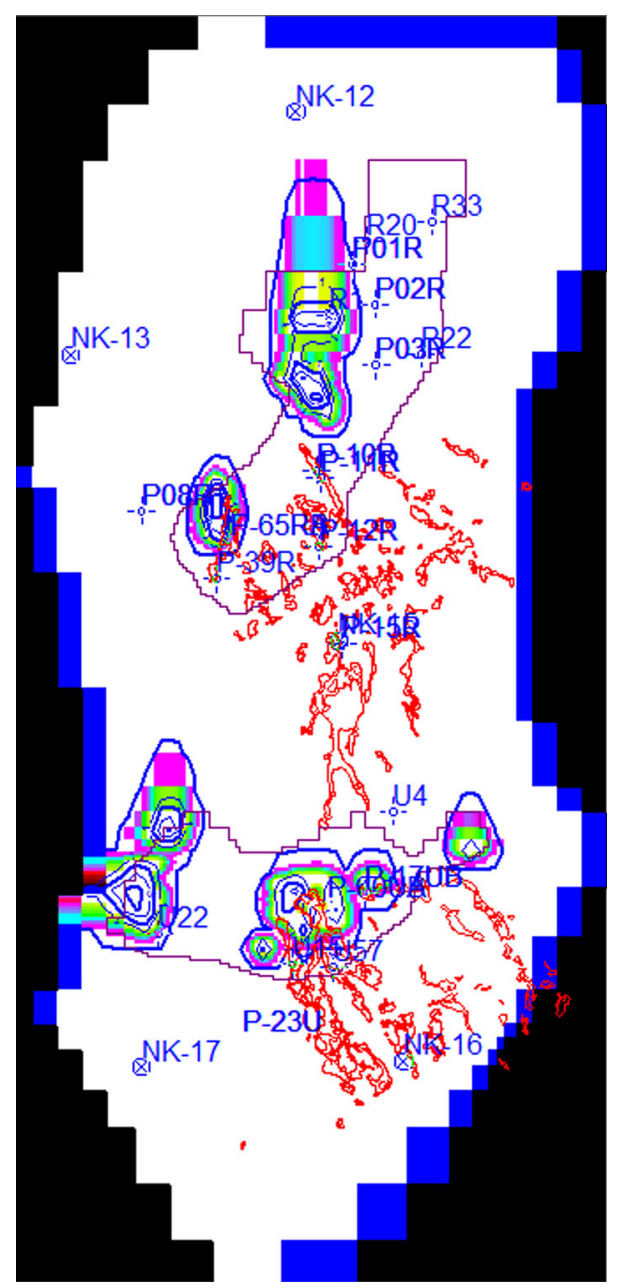

Fig. 5 Predicted distributions of TPH plume extent in 73 years (1991-2063) for source removal scenario. Pink shaded is low concentration areas and green is high areas. Red lines show contamination source areas, Freshwater lenses boundaries are shown in purple

extraction well, over time reducing the total mass of contaminants in the formation as well as reducing concentrations.

The extracted water may be treated and used for beneficial uses such as irrigation, reinjection, or other suitable uses. This section focuses on the pump-treat-reinject option.

In this study, PTR involves the pumping of water from the aquifers, treatment to remove hydrocarbons (and other contaminants as required) and desalination to reduce the total dissolved solid concentration before reinjection of the cleaned water back to the aquifer. The concept of PTR involves the washing of predominantly dissolved contaminants through the affected formation by injecting clean water and extracting contaminated water and is straight forward; however, in reality making such a scheme work efficiently is complex and depends on many variables. In the first instance, this was undertaken using analytical methods (two dimensional calculations). This approach allowed the minimum requirements for a PTR system to be assessed before modelling thereby reducing the trial and error time required to realise a workable system. The preliminary outcomes of the analytical assessment were as follows:

- a large number of pumping bores are required, potentially up to 51 in Al Raudhatain and 43 in Umm AlAish;

- individual bores are required to be screened in individual aquifers;

- the individual bore pumping rates (based on the specific capacity distribution) are generally low being less than $3 \mathrm{~L} / \mathrm{sec}$ for Al-Raudhatain and $2 \mathrm{~L} / \mathrm{sec}$ for Umm AlAish;

- the pumping bore capture zone should not be larger than $300 \mathrm{~m}$ which dictates a bore spacing of not more than approximately $600 \mathrm{~m}$;

- treated water quality for injection should be less than or equal to $1000 \mathrm{mg} / \mathrm{L}$ TDS and $0.0001 \mathrm{mg} / \mathrm{L} \mathrm{TPH}$;

- reinjection may require less or the same number of bores as required for pumping;

- the reinjection bores should be placed within the freshwater lens; and.

- there is an assumed 5\% loss of water due to desalination which may need to be made up from sources outside the basins.

\section{General set-up and parameter values}

The modelling presented here was used to test the feasibility and timeframes for remediation of the contamination in groundwater at Raudhatain and Umm Al-Aish freshwater lenses using the pump treat reinject option for treated water.

Initially, it was assumed that pumping bores would be within the area(s) of contamination with the injection bores located outside to "drive" the contamination to the pumping bores. However, preliminary analytical modelling indicated issues with this design such as upwelling of saline water, plume diving and inability to control the movement of the contamination plumes.

Given the aim is to remediate the freshwater lenses which occur over two aquifers and contamination recharge is mainly via overland flow and vertical recharge during rainfall events, the pumping and reinjection bores were required to be placed within the lenses in the area of contamination. It also became apparent that three to four times the storage volume is required to be treated to achieve adequate "washing" of contaminants from the aquifer. 


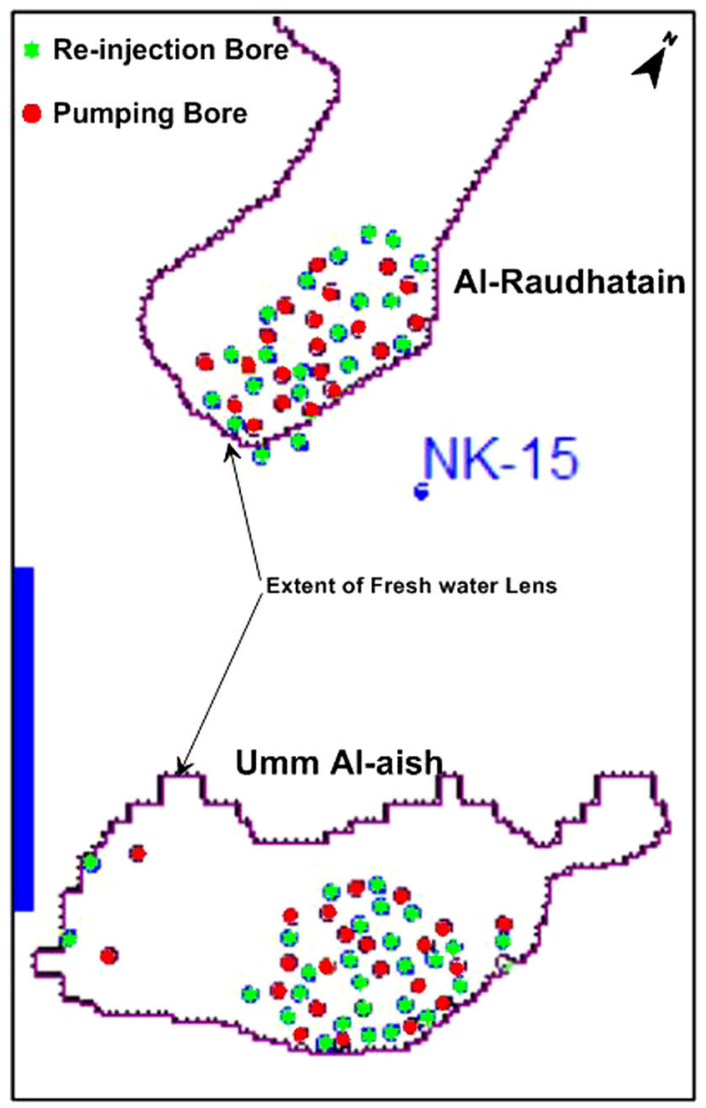

Fig. 6 Pumping and reinjection bore location plan

The preliminary information on the layout of the PTR system from the analytical analysis was entered into the model, the aim being to achieve a reasonable capture and removal of the contaminant mass. Initially, extraction bores were located throughout the freshwater aquifers to enable adequate capture of contamination depicted after 50 years. These required approximately 100 wells in Umm Al-Aish and 80 wells in Raudhatain, each pumping at approximately $140-200 \mathrm{~m}^{3} /$ day. Each well then had a capture zone of maybe $300-500 \mathrm{~m}$. Wells were spaced at this interval across the two freshwater fields so as to capture possible pollutants emanating from the source areas. This requires many simulation runs to achieve convergence of the model with the adopted inputs. Preliminary parameters used are indicated below. The location of pumping and reinjection bores is shown in Fig. 6.

\section{Simulation results}

TPH contours depicted in Fig. 7 show the concentration contours after 73 years (50 years of PTR). The preliminary result shows that the PTR scenario is a viable option. A reasonable capture and removal of the contaminant mass has occurred via this simulation compared to the do

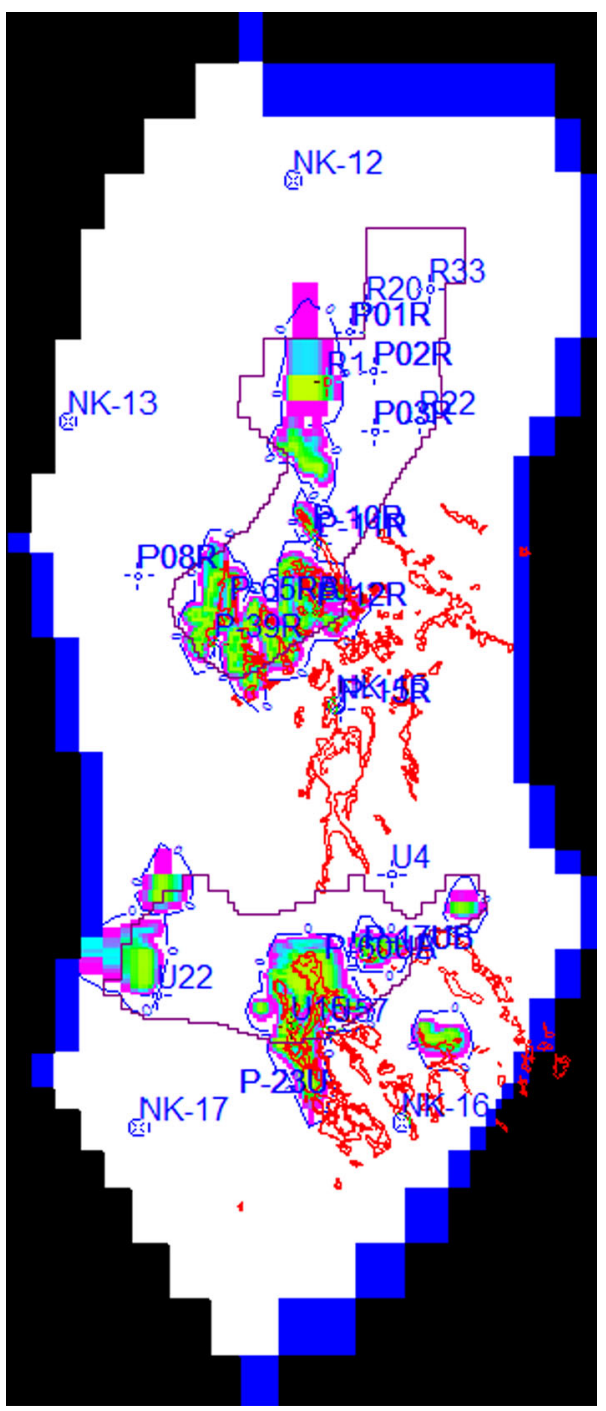

Fig. 7 Predicted distributions of TPH plume extent in 73 years (1991-2063) for PTR scenario-Pink shaded is low concentration areas and green is high areas. Red lines show contamination source areas, Freshwater lenses boundaries are shown in purple

nothing scenario. The relative reduction in the area of the 1500 and $0.01 \mathrm{mg} / \mathrm{L}$ contours (for both Raudhatain and Umm Al-Aish) is approximately 35 and $30 \%$, respectively, although not all the TDS/TPH is removed after 50 years of pump and treat.

However, since residual pollution remains in the aquifer, some greater level of optimisation is required to optimise placement of bores and adjust pumping and re-inject rates to achieve more effective capture and removal of the contamination and hence significantly improve the cleanup. Further optimisation may allow assessment of reasonable timeframes to achieve technical remediation. Based on the preliminary runs, the maximum yielding capacity of any bore is about $450 \mathrm{~m}^{3} /$ day $(5.2 \mathrm{~L} / \mathrm{sec})$. 


\section{Preferred remediation option}

Three options have been considered in this study through simulation:

- do nothing-natural attenuation;

- source removal; and,

- pump-treat-reinject.

The do nothing option will not meet the remediation targets as there are likely large sources of contamination within the vadose zone which will be mobilised over time.

The source removal option is not considered viable (or beneficial) as removal of the top several metres of dry and wet oil lakes will likely not remove the larger source of contamination which is in the vadose zone and reaches depths of at least $25 \mathrm{~m}$. In addition, this remediation option may likely result in a spike in contaminant concentrations post-removal, due to increased recharge and mobilisation. On the positive, removal of the lakes will speed up natural remediation of the lakes and underlying land in the long term and may be considered as part of a larger remediation strategy.

Pump-treat-reinject, based on the preliminary runs, indicates the method may be effective in remediation of the freshwater aquifers. Therefore, PTR is the preferred remediation option (based on the modelling).

For future optimisation, a physically based management optimisation (PBMO) is suggested as the preferred tool because it integrates physics-based groundwater flow and transport models, management science and nonlinear optimisation tools to provide stakeholders with practical, optimised bore placement locations and flow rates for remediating contaminated groundwater at complex sites (e.g. Deschaine et al. 2013) where the algorithm implementation, verification and effectiveness testing was conducted, in comparison with other optimisation tools which require multiple simulation stops and starts, unable to solve complex problems in reasonable time frames, and have embedded flow and transport simulators with limited capabilities, accelerates site closure, and achieves cost savings and minimises long-term liabilities (e.g. Deschaine and Lillys 2011).

To fully assess the effectiveness of the pump and treat and reinject option further optimisation of the PTR and design of the field trial system, optimisation of monitoring bores, both current and planned, PTR pilot field trials, recalibration of the model and assessment of the results to confirm effectiveness and optimisation of the expansion of the pilot trial for further trials or full-scale remediation are required.

The pump and treat and reinject scenario although appearing to be effective will require further optimisation of the model over many model runs, and with field pilot trials in order confirm the feasibility of this option. Future optimisation of the PTR option will refine the bore layout and pumping/reinjection rates to maximise the simulated clean-up, including assessing how much of the contamination has been removed from the aquifer and weather ongoing pumping will only marginally improve remediation over the extra estimated years of pumping. Regardless, field pilot trials are required to advance this option to the feasibility stage.

\section{Conclusions}

A numerical model was developed during the course of the study to simulate the flow and transport of the hydrocarbon pollutants in the groundwater of the study area with the passage of time.

The scenarios simulated indicate the do nothing approach will likely not achieve the target water quality within 50 years and neither would source removal, assuming it were feasible.

This modelling approach has several advantages including that both basins are modelled together and the model is calibrated and converges. This model will therefore benefit the stakeholders in the remediation of the freshwater aquifers as it will allow model updates with new data as it comes to hand and verification of remediation against predicted and continuous refinement and optimisation of remediation practices.

The model is a very powerful tool in visualising groundwater conditions over time, planning and most effectively and efficiently implementing groundwater remediation, monitoring the success of groundwater remediation of the aquifers, deciding which bores are not effective or should be decommissioned, identifying bores located up-gradient and not along the centreline of the plume front and communicating through visualisation, aided by the graphic packages, the key aspects of the remediation to stakeholders.

This study suggests that the groundwater in the Umm Al-Aish basin has been significantly affected by hydrocarbon pollutants and it is predicted that these pollutants would move towards the Al-Raudhatain bore field if no preventive and/or remedial measures are taken in the near future. Based on the findings of the study, a number of steps were suggested to effectively manage the groundwater resources to reduce the risk of further groundwater deterioration in that area.

The groundwater quality data and hydrogeological studies from the period 1991 to 2013 have helped in the development of groundwater flow and mass transport models of total dissolved solids and total petroleum hydrocarbon associated with the 1991 Gulf War. The mass 
transport model has predicted extent of the total dissolved solids plume in groundwater over the 23 year period (1991-2013). The model results indicate that groundwater flow direction is partially responsible for the elevated total dissolved solids reported in monitoring bores at Umm AlAish. It is assumed that the total dissolved solids concentration will influence the movement of total petroleum hydrocarbon in groundwater with its effective retardation factor of 1.2, whereas total dissolved solids move without retardation.

The mass transport modelling results depict the likely total petroleum hydrocarbon migration pattern in the worstcase scenario. This prediction indicates that even though the present day total petroleum hydrocarbon loading is negligible in the centre of the Al-Raudhatain depression, what has earlier entered the groundwater system from the contamination sources (pits, fringes and lakes) is still moving in the groundwater towards the freshwater lenses, and is likely undetected due to a lack of optimal monitoring bore screen depth.

The remediation scenarios simulated indicate the do nothing approach would not achieve the target water quality within 50 years neither would complete source removal.

Pump-treat-reinject simulations indicate that significant remediation of the freshwater aquifers can be achieved within 50 years with a reduction in the area of the $0.01 \mathrm{mg} /$ L concentration contour of $30 \%$ for both Raudhatain and Umm Al-Aish.

Challenges remain in understanding the impacts of chemical and biological heterogeneity, pore-scale interactions, and mixing on the fate of organic contaminants. Further effort is needed to successfully incorporate these processes into field-scale predictions of transport and fate. The preferred remediation option (namely, pump-treatreinject) must be validated at field pilot trial level in each aquifer at a small scale. It shall include developing an appropriate sub-model, comprehensive monitoring, sample analysis to allow recalibration of the model. Based on the updated results from the detailed pilot studies, the fullscale and long-term groundwater remediation will be implemented using the prepared model which will be crucial for decision making process for choosing remediation techniques, formulating remediation strategies and to manage the water resources. In summary, relevance fields of studies can be benefitted from point-source contaminant research advances. These include geologic carbon sequestration, nonpoint-source contamination, aquifer storage and recovery, the fate of contaminants from oil and gas development, and enhanced bioremediation.

Acknowledgements The authors would like to thank the Kuwait National Focal Point for Environmental Projects, Ministry of
Electricity and Water in Kuwait-Groundwater Sector and SMEC international for providing access to some of their data. The manuscript has benefitted from the reviewers' comments.

Open Access This article is distributed under the terms of the Creative Commons Attribution 4.0 International License (http:// creativecommons.org/licenses/by/4.0/), which permits unrestricted use, distribution, and reproduction in any medium, provided you give appropriate credit to the original author(s) and the source, provide a link to the Creative Commons license, and indicate if changes were made.

\section{References}

Al-Weshah R, Yihdego Y (2016) Modelling of strategically vital fresh water aquifers, Kuwait. Environ Earth Sci 75:1315. doi:10. 1007/s12665-016-6132-1. http://link.springer.com/article/10. $1007 / \mathrm{s} 12665-016-6132-1$

Deschaine LM, Lillys TP (2011) PBMO: the comprehensive physicsbased flow, transport, and management optimization tool kit. Presented at the federal remediation technologies roundtable, Washington, DC

Deschaine LM, Lillys TP, Pinter JD (2013) Groundwater remediation design using physics-based flow, transport, and optimization technologies. Environ Syst Res 2:6

Doherty J (2004) PEST: model-independent parameter estimation, user's manual: $5^{\text {th }}$ edition. Watermark numerical computing, Brisbane, Australia, p 336

Essaid IH, Bekins AB, Cozzarelli MI (2015) Organic contaminant transport and fate in the subsurface: evolution of knowledge and understanding. Water Resour Res 51(7):4861-4902

Grealish G, Omar S, Quinn M (1998) Affected area soil surveyassessing damage magnitude and recovery of the terrestrial ecosystem-follow-up of natural and induced desert recovery. Kuwait Institute for Scientific Research, Report No. KISR, Kuwait

Grealish G, Omar S, Quinn M (2001) “As Sabriyah and ArRawdatayn oil affected area soil survey, assessing damage magnitude and recovery of the terrestrial eco-system/follow up of natural and induced desert recovery", AACM and KISR, Project FA015C

Guvanasen V, Himml M, Buechler B (2009) Simulation of kineticlimited degradation of multi-component hydrocarbons with particular consideration on the supply of electron acceptors. International Symposium on Efficient Groundwater Resources Management "The Challenge of quantity and Quality for Sustainable future", Bangkok, Thailand

Hu H, Mao X, Barry DA, Liu C, Li P (2015) Modeling reactive transport of reclaimed water through large soil columns with different low-permeability layers. Hydrogeol J 23(2):351-364

HydroGeoLogic Inc. (HGL) (2013) MODFLOW-SURFACT ${ }^{\mathrm{TM}}$ Version 4.0; User's manual and guide. VA, USA

KISR (2009) Long-term monitoring and remediation strategy for hydrocarbon pollutants in the groundwater of Al-Raudhatain and Umm Al-Aish fields (Volume-1). WM016C. Hydrology Department Water Resources Division, Kuwait Institute for Scientific Research

Omar SA, Al-Sdirawi MA, Razzaque MA (1994) "Agricultural and environmental laws, policies and regulations.” KISR, Report No. KISR4523, Kuwait

Panday S, Huyakorn PS (2008) MODFLOW SURFACT: a state-ofthe-art use of vadose zone flow and transport equations and

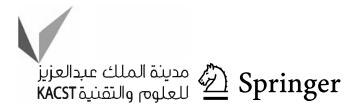


numerical techniques for environmental evaluations. Vadose Zone J 7(2):610-631

Parsons (1964) Groundwater Resources of Kuwait. Vols I, II and III. Ministry of Electricity and Water, Kuwait

Rasa E, Bekins BA, Mackay DM, De Sieyes NR, Wilson JT, Feris KP, Wood IA, Scow KM (2013) Impacts of an ethanol blended fuel release on groundwater and fate of produced methane: simulation of field observations. Water Resour Res 49(8):4908-4926

Sadiq M, McCain JC (1993) The Gulf War aftermath-an environmental tragedy. Kluwer Academic Publishers, Berlin, p 84

SMEC (2006) GD 5.12 — "Groundwater damages and remediation of the Raudhatain and Umm Al-Aish freshwater aquifers of Kuwait". Program for the monitoring and assessment of the environmental consequences of the Iraqi aggression in Kuwait

SMEC (2014). Groundwater modelling of the Rawdhatain and Umm Al-Aish freshwater aquifers of Kuwait. Program for the monitoring and assessment of the environmental consequences of the Iraqi aggression in Kuwait

Somaratne N, Zulfic H, Ashman G, Vial H, Swaffer B, Frizenschaf J (2013) Groundwater risk assessment model (GRAM): groundwater risk assessment model for wellfield protection. Water 5:1419-1439. doi:10.3390/w5031419

Suthersan S, Gentile M, Bell C, Quinnan J, Horst J (2016) Big data and environmental remediation: gaining predictive insights. Groundw Monit Remediat J 36(2):21-31. doi:10.1111/gwmr. 12156

Yihdego Y (2015) Water reuse and recreational waters, chap 78. In: Eslamian S (ed) Urban water reuse handbook (UWRH). Taylor and Francis, CRC Press, pp 1029-1039, 1141. ISBN: 978-14822-2914-1. doi:10.1201/b19646-97. https://www.crcpress. com/Urban-Water-Reuse-Handbook/Eslamian/p/book/97814822 29141

Yihdego Y (2016a) Drought and pest management initiatives, chap 11. In: Eslamian S, Eslamian FA (eds) Handbook of drought and water scarcity (HDWS). Management of drought and water scarcity, vol 3. Francis and Taylor, CRC Group (in press). https://www.crcpress.com/Handbook-of-Drought-and-Water-Scar city-Environmental-Impacts-and-Analysis/Eslamian-Eslamian/p/ book/9781498731041

Yihdego Y (2016b) Drought and groundwater quality in coastal area, chap 15. In: Eslamian S, Eslamian FA (eds) Handbook of drought and water scarcity (HDWS). Environmental impacts and analysis of drought and water scarcity, vol 2. Francis and Taylor, CRC Group (in press). https://www.crcpress.com/Handbook-of-
Drought-and-Water-Scarcity-Environmental-Impacts-and-Analy sis/Eslamian-Eslamian/p/book/9781498731041

Yihdego Y, Al-Weshah R (2016a) Gulf war contamination assessment for optimal monitoring and remediation cost-benefit analysis, Kuwait. Environ Earth Sci 75(18):1-11 doi:10.1007/ s12665-016-6025-3. http://link.springer.com/article/10.1007\% 2Fs12665-016-6025-3

Yihdego Y, Al-Weshah R (2016b) Assessment and prediction of saline sea water transport in groundwater using using 3-D numerical modelling. Environ Process J. doi: 10.1007/s40710016-0198-3. http://link.springer.com/article/10.1007/s40710016-0198-3

Yihdego Y, Al-Weshah R (2016c) Hydrocarbon assessment and prediction due to the Gulf War oil disaster, North Kuwait. J Water Environ Res. doi: 10.2175/106143016X14798353399250

Yihdego Y, Eslamian S (2016) Drought management initiatives and objectives, chap 1. In: Eslamian S, Eslamian FA (eds) Handbook of drought and water scarcity (HDWS). Management of drought and water scarcity, vol 3. Francis and Taylor, CRC Group (in press). https://www.crcpress.com/Handbook-of-Drought-andWater-Scarcity-Environmental-Impacts-and-Analysis/EslamianEslamian/p/book/9781498731041

Yihdego Y, Paffard A (2016) Hydro-engineering solution for a sustainable groundwater management at a cross border region: case of Lake Nyasa/Malawi basin, Tanzania. Int J Geo Eng. doi: 10.1186/s40703-016-0037-4

Yihdego Y, Webb JA (2015) Use of a conceptual hydrogeological model and a time variant water budget analysis to determine controls on salinity in Lake Burrumbeet in southeast Australia. Environ Earth Sci J. 73(4):1587-1600. http://link.springer.com/ article/10.1007/s12665-014-3509-x

Yihdego Y, Webb JA (2016) Assessment of wetland hydrological dynamics in a modified catchment basin: case of Lake Buninjon, Victoria, Australia. Water Environ Res J. doi: 10.2175/ 106143016X14798353399331

Yihdego Y, Danis C, Paffard A (2015) 3-D numerical groundwater flow simulation for geological discontinuities in the Unkheltseg Basin, Mongolia. Environ Earth Sci J. 73(8):4119-4133. doi: 10. 1007/s12665-014-3697-4. http://link.springer.com/article/10. 1007/s12665-014-3697-4

Yihdego Y, Reta G, Becht R (2016) Human impact assessment through a transient numerical modelling on The UNESCO World Heritage Site, Lake Navaisha, Kenya. Environ Earth Sci. doi: 10. 1007/s12665-016-6301-2 